\section{Emails of co-authors:}

\section{Chris Soulsby: c.soulsby@abdn.ac.uk}

14 Abstract: Climate change projections indicate reduced summer precipitation and increased air 15 temperature for the northern high latitudes. These climate changes are likely to alter forest water budgets of which plant transpiration $(T)$ (T) forms a significant component. Plant transpiration is regulated by stomata behavior of particular species, which is constrained by ambient air and soil conditions. Here, we measured sap flow in a Scots pine (Pinus Sylvestris)

\section{Assessing the environmental controls on Scots pine transpiration and the} Hailong Wang*, Doerthe Tetzlaff, Jonathan J. Dick, Chris Soulsby Scotland, AB24 3UF, UK

*Corresponding to Hailong Wang, hailong.wang@abdn.ac.uk; whl84@hotmail.com; +44 1224272342

\section{Doerthe Tetzlaff: d.tetzlaff@abdn.ac.uk}

\section{Jonathan Dick: jonathan.dick@abdn.ac.uk} plantation in a low energy Scottish headwater catchment during the main summer growth 
20 period. Effects of rainfall on forest transpiration, as well as the response of $T$ to four 21 environmental variables were investigated at a daily scale. In this boreal environment, 22 transpiration was mainly restricted by radiation and vapor pressure deficit. Air temperature was 23 the least important controlling factor. Soil water became an important factor when rainfall was

24 limited. Frequent but small rain events dictated that precipitation met short-term transpiration 25 demand most of the time. The trees needed supplementary water from antecedent soil water 26 stores when weekly rainfall was below $\sim 8 \mathrm{~mm}$, but such periods were rare. Water exchange 27 mainly occurred in the canopy or upper $10 \mathrm{~cm}$ of the soil, with $47 \%$ of rainfall transpired, $45 \%$ 28 intercepted and $<8 \%$ evaporated from the soil surface. Understanding interactions between 29 forests and their hydroclimate, as well as the role of forests in water partitioning is crucial to 30 assist a sustainable land and water management in a changing climate. Whilst such studies are common in semi-arid regions, they are limited in boreal zones, therefore, our findings are a valuable contribution to understanding plant-water relations in a changing environment.

33 Key words: sap flow; evapotranspiration; climate; hydrology; water partition; Scots pine 


\section{Introduction}

Plant transpiration ( $T$ ) plays an important role in forest water budgets, as it affects the water partitioning in soils, aquifers and streams (Le Maitre et al., 1999; Vivoni et al., 2008; Deutscher et al., 2016). Precipitation has increased in the Northern Hemisphere over the last two to three decades (Easterling et al., 2000; Dore, 2005; IPCC, 2013) which can impact northern ecosystem composition and productivity (Lindner et al., 2008; Ruckstuhl et al., 2008; Chertov et al., 2010). While annual precipitation is predicted to further increase in the future (IPCC, 2013; Krasting et al., 2013), summer rain is projected to decrease in many northern areas possibly falling in fewer higher intensity events (Lindner et al., 2008; IPCC, 2013). In such circumstances, plants may face severe challenges to maintain productivity with foreseeable more frequent occurrence of water stress strongly associated with the precipitation and soil moisture dynamics (Porporato et al., 2001; Lisar et al., 2012). Therefore, a comprehensive understanding of the precipitation effects and soil water controls on plant water use is necessary and holds the key to adapting water and land use management to the future climate change.

$T$ is regulated by stomata behavior constrained by both atmospheric conditions and soil water availability (Whitehead, 1998; Buckley et al., 2003; Wang et al., 2014). The mechanisms have been extensively explored at multiple scales from stomata and leaf to whole tree and ecosystem levels (Jarvis and McNaughton, 1986; Schulze et al., 1994; Bovard et al., 2005). Among the constraining variables, atmospheric vapor pressure deficit (VPD) and solar radiation (Rs) are the two major dominant controlling factors (Bovard et al., 2005). However, secondary controlling factors (such as temperature, $T a$, soil water content, $\theta$ ) vary with climates and species (Guo et al., 2010; Chen et al., 2014). In addition, rainfall can also affect $T$ by altering atmospheric demand (or potential evapotranspiration, ETp) and soil water content (Findell and Eltahir, 1997). For example, rainless days usually create more favorable conditions for 
transpiration (higher $R s$ and $V P D$ ) than rainy days. In arid/semi-arid areas, where vegetation growth is usually water-limited, plant water use highly relies on rainwater, and rainfall pulses stimulate $T$ after a certain rainfall threshold is reached, because increased water storage in the root zone increases soil water availability (Ogle and Reynolds, 2004; Potts et al., 2006; RazYaseef et al., 2012).

In contrast to semi-arid regions, in the low-energy northern high latitudes $\left(>45^{\circ} \mathrm{N}\right)$ vegetation growth is usually limited by radiation and not water availability. The studies in this region put a stronger focus on climate-driven vegetation greening attributed mainly to warming temperatures (Buitenwerf et al., 2015; Garonna et al., 2016). Precipitation, soil moisture, and snow accumulation and melt also contribute to enhanced vegetation growth (Luus et al., 2013), and this contribution can be highly variable in space and time (Barichivich et al., 2014). As the treeline has progressed poleward (Beringer et al., 2005; Pearson et al., 2013), investigations of tree water use and environmental controls are important for understanding ecosystem response to climate change, but such work in this critical region has so far been limited. Several studies have shown that tree water use in the high latitudes is often closely linked to permafrost thaw since soil water from thawed permafrost can be comparable to soil water from summer rains (Kropp et al., 2017). Light intensity and humidity also closely restrict tree water use and productivity (Arneth et al., 1996; Gao et al., 2016; Zha et al., 2013). There is a lack of understanding on direct rainfall effects.

The natural vegetation over much of the Scottish Highlands would have been forest dominated by Scots pine (Pinus sylvestris), but a long history of clearance, burning and overgrazing by deer and sheep resulted in limited forest cover across Scotland. With the presence of frequent 
82 of the year (Haria and Price, 2000). However, future projections of decreased rainfall and increased intensity during growing seasons (Gosling, 2012; Capell et al., 2013) may result in a decreased water availability increasing the probability that vegetation would suffer from more frequent and prolonged water stress (Zhang et al., 2008; Trahan and Schubert, 2016). The role of soil water in regulating plant transpiration may become more important (Geris et al., 2015b) but it is not yet fully understood; neither is the role of plant transpiration on canopy water partitioning relative to interception and soil evaporation losses. Therefore, in this study, we measured sap flow in a Scots pine plantation in a Scottish headwater catchment, aiming to: (1) investigate the dynamics of transpiration in Scots pine in this low energy boreal environment in the summer season which may be more water-limited than other seasons; (2) examine the interactive environmental controls on transpiration; and (3) understand the implications for water partitioning in the forest in terms of likely effects of future climatic conditions.

\section{Materials and methods}

\subsection{Study site}

This study was conducted in the Bruntland Burn catchment $\left(3.2 \mathrm{~km}^{2}, 57.04^{\circ} \mathrm{N}, 3.13^{\circ} \mathrm{W}\right)$ in the Scottish Highlands (Figure 1). It is described in detail elsewhere (Birkel et al., 2011; Tetzlaff et al., 2014; Soulsby et al., 2015; Blumstock et al., 2016). The climate is boreal oceanic; the recent decadal mean annual maximum temperature is $19.4 \pm 1.3^{\circ} \mathrm{C}$ in July, and mean annual minimum temperature is $-1.0 \pm 1.6^{\circ} \mathrm{C}$ in January. Mean annual precipitation $(P)$ is around 1000 $\mathrm{mm}$; it is relatively evenly distributed but lowest (mean $\sim 65 \mathrm{~mm} / \mathrm{month}$ ) in April-July and highest ( 105 mm/month) in October-February. Throughout the year, it most commonly falls

103 as low-intensity rain; snow is generally $<5 \%$ of annual $P$ and tends to lie for short periods (a 104 few days to a few weeks) in January and February and melts quickly. Annual potential 


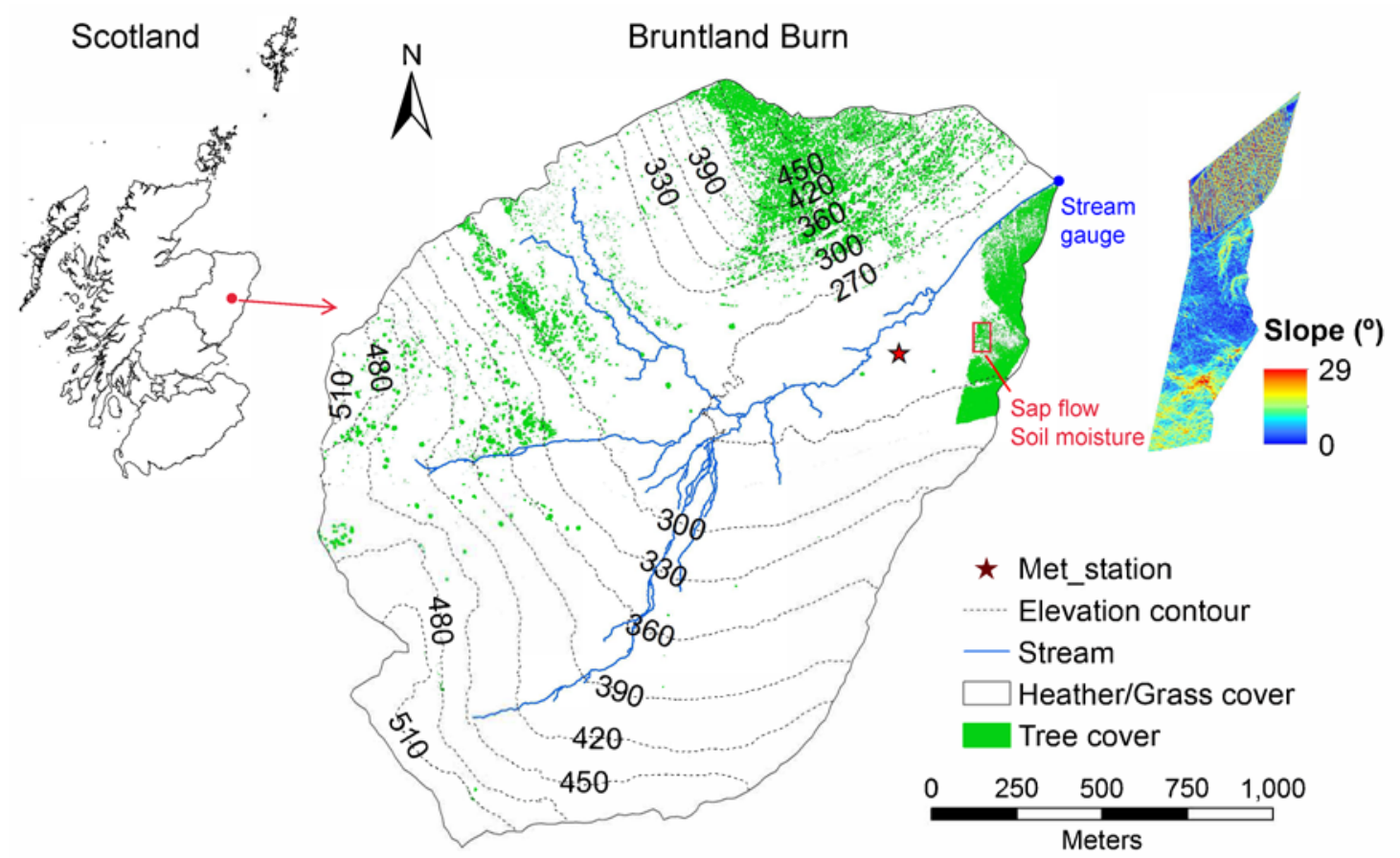

Figure 1 Location of the Bruntland Burn catchment on the map of Scotland, and vegetation cover and instrumentation in the catchment. The forest plot is enclosed by the red rectangle. Numbers on contour lines are elevation in meters above sea level. Vegetation cover and slope data were obtained from $1 \mathrm{~m}$ resolution LiDAR data. Slopes at the lower part of the plantation are affected by the furrows.

114 The geology of the catchment is mainly granite and associated metamorphic rocks (Tetzlaff et

115 al., 2014; Dick et al., 2015). Elevation ranges from around 250 m.a.s.l at the flat valley bottom,

116 to about $550 \mathrm{~m}$ on the steeper slopes (Figure 1). Organic-rich soils dominate the catchment,

117 with large areas of deep $(>1 \mathrm{~m})$ peats in valley bottoms and shallow $(<0.5 \mathrm{~m})$ peats on the lower

118 hillslopes. The steeper slopes with the studied plantation are characterized by podzols which

119 have a 0.1-0.2 m deep O horizon overlying a freely draining mineral sub-soil. 
120 The dominant vegetation in the catchment is heather (Calluna vulgaris and Erica tetralix)

121 shrubs with a canopy height $\sim 0.3-0.6 \mathrm{~m}$, distributed throughout the valley and hillslopes. Trees,

122 mostly Scots pine, cover about $10 \%$ of the catchment, mainly in plantations near the outlet and

123 as natural forest on the south-facing steeper slopes. The tree height ranges from $5 \mathrm{~m}$ in the

124 natural forest to $15 \mathrm{~m}$ in the plantation. The understory is sparsely vegetated in the plantation

125 where canopies are dense and light penetration is low. The majority of tree roots are present in 126 the upper $0.3 \mathrm{~m}$ of the soils (Geris et al., 2015a) but extend a few meters horizontally. Trees 127 are $~ 30$ years old without any cutting/thinning history. Tree density is lower in the middle part 128 of the forest (960 trees/ha) than the upper and lower parts ( $>2000$ trees/ha).

\subsection{Measurements}

This study covers July to September 2015, a period in the year that is usually the warmest and driest. In total, 32 sets of Granier-type (Granier, 1987) thermal dissipation sap flow probes

132 (TDP probes, Dynamax Inc. Huston, USA) were installed on 10 trees at $1.3 \mathrm{~m}$ high above 133 ground with a range of stem sizes $(10-32 \mathrm{~cm}$ in diameter at breast height, $D B H)$. Each set of sensors comprises 1 heater probe and 1 thermocouple probe $4 \mathrm{~cm}$ below it. Four sensors were installed on trees with $\mathrm{DBH}$ over $20 \mathrm{~cm}$ in four cardinal directions; two or three sensors on trees with $D B H$ of 15-20 cm on the south-north (and west when applying) sides; and one sensor on 1 tree with $\mathrm{DBH}$ below $15 \mathrm{~cm}$. Data were collected using a CR1000 data logger (Campbell Scientific, USA) at an hourly interval. Incremental wood cores were taken from 51 trees in 3 plots in the plantation at the end of study period to establish the relationship between sapwood area $(A s)$ and $D B H$ at $1.3 \mathrm{~m}$ above ground ( $A s=0.0049 \times D B H^{2.0048}, R^{2}=0.95$ ). The average

141 ratio of sapwood area to forest area $\left(25 \mathrm{~m}^{2} / \mathrm{ha}\right)$ obtained from surveys in the three plots was 142 used to estimate forest transpiration. 
143 An automatic weather station (Environmental Measurement Limited, North Shields, UK) was

144 established near the forest site in an open area (Figure 1), giving continuous measurements of

145 air temperature $(T a)$, relative humidity $(R H)$, net radiation $(R n)$, soil heat flux $(G)$, precipitation

$146(P)$, wind speed/direction, and atmospheric pressure. Volumetric soil water content $(\theta)$ was

147 measured near the sample trees using time domain reflectometry (TDR) soil moisture probes

148 (model CS616, Campbell Scientific, Inc. USA). Sensors were calibrated against gravimetric

149 soil water content and bulk density in the lab with a range of water content. Two replicate TDR

150 probes were inserted at depths of $0.1,0.2$ and $0.4 \mathrm{~m}$ prior to the sap flow measurements

151 commencing, allowing soil stabilization after refilling of the pits. The slopes derived from a 1

152 m resolution LiDAR elevation map (Figure 1) show that most of the plantation is relatively flat.

153 Measurement of soil moisture at one location will not capture the spatial heterogeneity within

154 the plantation, but comparison to measurements elsewhere in the catchment showed that the

155 sensors at this site captured the general soil water dynamics in response to rainfall and

156 evapotranspiration. Meteorological parameters and soil water content measurements were

157 recorded by CR800 data loggers (Campbell Scientific, Inc. USA) at 15-minute intervals.

\subsection{Methods}

Forest transpiration was estimated using the average sap flux density per unit sapwood area

160 multiplied by the sapwood area index (Granier et al., 1996). Measurements of forest

161 transpiration and hydroclimatic variables, including $T a$, vapor pressure deficit (VPD, calculated from mean $T a$ and $R H$, Allen et al., 1998), $R n$ and $\theta$, were aggregated to daily values for comparison of temporal dynamics. We used two measures to investigate the potential effects of rainfall on transpiration. First, we calculated the mean diel $T$ rates $(\mathrm{mm} / \mathrm{h})$ on days before rain and after rain. Second, we grouped rainfall data into different amount classes

166 (mm/d), and then calculated the increases in $T$ on days after rain in comparison to prior to rain 
167 for each rainfall class, in order to examine the effects of different rainfall amounts on tree water

168 use. "Before rain” refers to the day before one or several rain days; "after rain” refers to the

169 day when $T$ peaked after the same rainy day(s) (Zeppel et al., 2008; Zhao and Liu, 2010). Daily

170 rainfall $<0.2 \mathrm{~mm}$ was considered as rain free. There were 13 pairs of before-rain and after-rain

171 days for the calculations.

172 Relationships between $T$ and environmental variables ( $T a, V P D, R n, \theta$ ) were analyzed using

173 linear regression to investigate the major influencing factors on transpiration. Despite various

174 functions published to capture the effects of these environmental variables (Whitley et al., 2013;

175 Wang et al., 2016), here, we used a linear regression as the data ranges of all examined variables

176 at this site were much smaller than those found in other studies (McLaren et al., 2008). Since

$177 T$ can be estimated as the multiplication of canopy conductance and leaf-air vapor pressure

178 deficit (Jarvis and McNaughton, 1986; Whitehead, 1998), the ratio T/VPD can be considered

179 as a proxy of canopy conductance. In this sense, we analyzed the relationships between $T$ and

180 the environmental variables at different ranges of T/VPD to differentiate the interactive controls

181 of atmospheric and soil water on $T$. 
182

183

184

185

186

187

188

189

190

191

192

193

194

195

196

197

\section{Results}

\subsection{Hydroclimatic measurements}
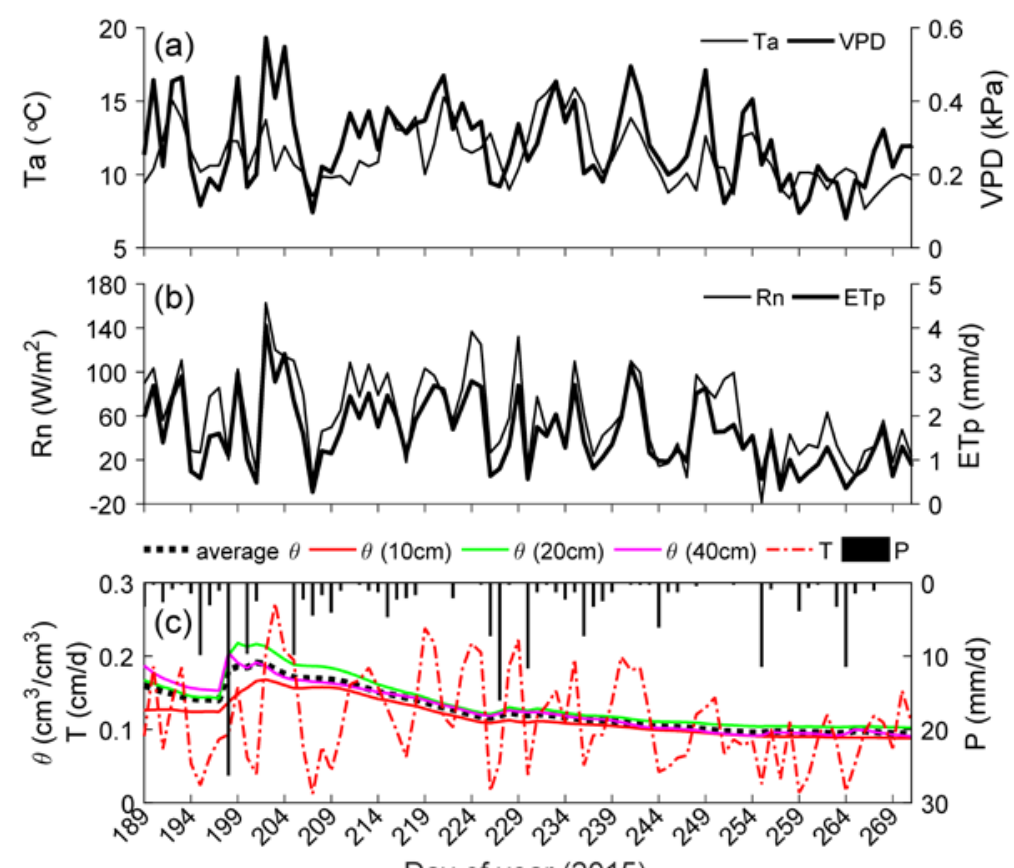

Day of year (2015)

Figure 2 Daily dynamics of hydroclimatic variables during the study period 8/7-28/9/2015. (a) mean air temperature ( $T a$ ) and vapor pressure deficit (VPD); (b) net radiation $(R n)$ and potential evapotranspiration (ETp); (c) Rainfall $(P)$, transpiration (T) and soil water content

$(\theta)$ at three depths $(10,20$ and $40 \mathrm{~cm})$ and depth-mean.

During the study period, variability in daily mean $\mathrm{Ta}$ was small with an average of $11.3^{\circ} \mathrm{C}$

(Figure 2a). Low temperature and high humidity resulted in a small range of $V P D(0.1-0.6 \mathrm{kPa})$.

Similarly, daily $R n$ values were small with the maximum only $\sim 180 \mathrm{~W} / \mathrm{m}^{2}$ (Figure $2 \mathrm{~b}$ ), showing a general decreasing trend over time. $T a, V P D$ and $R n$ were lower on rainy days (usually cloudy, cool and humid) than rain-free days (warm and less humid). Atmospheric demand (or ETp) corresponding to low radiation, temperature and high humidity only totaled $118.6 \mathrm{~mm}$ during the study period (83 days). There were frequent rainfall inputs, with most rain days characterized by small low-intensity events $(<5.0 \mathrm{~mm} / \mathrm{d}$, Figure $2 \mathrm{c})$. The podzolic soil was dry with a mean $\theta \sim 0.13 \mathrm{~cm}^{3} / \mathrm{cm}^{3}$. There was only one increase to about $0.2 \mathrm{~cm}^{3} / \mathrm{cm}^{3}$ on day of the 
year 198 (July 17) with rain >20 mm/d, followed by a gradual drying. Water content at $0.1 \mathrm{~m}$ depth was consistently the lowest, whereas it was highest at $0.2 \mathrm{~m}$ depth, however, the this likely reflects the location of the soil moisture sensors under a dense part of the forest canopy. Corresponding to the hydrometric conditions, transpiration rates were relatively low, usually $<2 \mathrm{~mm} / \mathrm{d}$ (Figure 2c) with more water transpired during rain-free days than rainy days. and $\theta$. Transpiration increased rapidly after rainy days, e.g., days 213-218, which was coincident with increasing $R n$ and VPD.

\subsection{Rainfall effects on transpiration}

209 To investigate the effects of rainfall on forest transpiration in more details, we calculated the

210 average diel transpiration rates on days before and after rain (Figure 3). Results were based on

21113 eligible data pairs. Across all dates, tree water uptake began at 08:00-09:00 in the morning

212 and peaked around 14:00-15:00 in the afternoon. The largest difference in transpiration rate

213 before and after rain occurred in the afternoon. On average, trees transpired $18.4 \%$ more water

214 on days after rain than they did on days before rain.

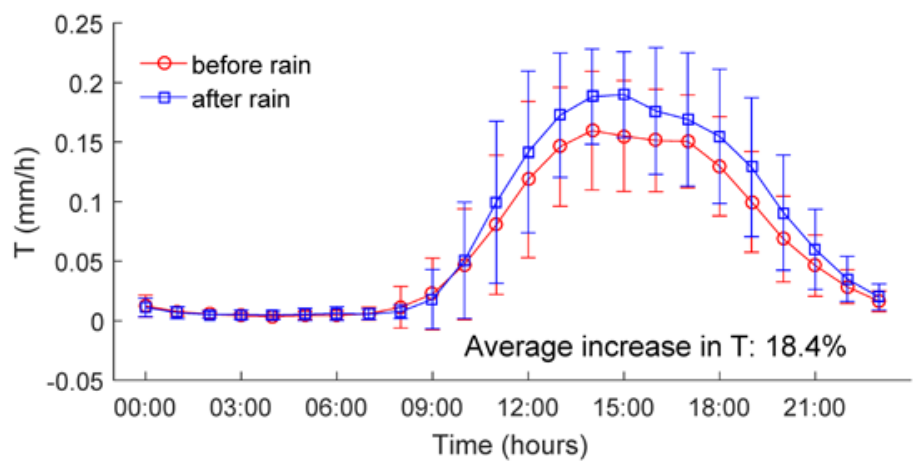


Figure 3 Comparison of mean diurnal transpiration $(T)$ on days before rain and after rain events. Before rain refers to the day before one or several consecutive rainy days; after rain means the day when $T$ peaked after the same rainy days.

219 The frequency of different rainfall amount classes and the increase in transpiration linked to each class are given in Figure 4. Most rain fell in small intensity events: almost half of the rainfall events had a rain amount less than $2.0 \mathrm{~mm} / \mathrm{d}$, one third of the events had rainfall of 2.0$5.0 \mathrm{~mm} / \mathrm{d}$, and only $22 \%$ of the events had rainfall over $5.0 \mathrm{~mm} / \mathrm{d}$. In Figure 4(b), the largest increase in transpiration occurred when rainfall was below $2.0 \mathrm{~mm} / \mathrm{d}(\sim 240 \%)$, followed by 2.0-5.0 $\mathrm{mm} / \mathrm{d}$. As rainfall amount increased, the relative increase in forest transpiration decreased. This means, frequent small rain events appear to have a more positive effect on transpiration than large rain events.
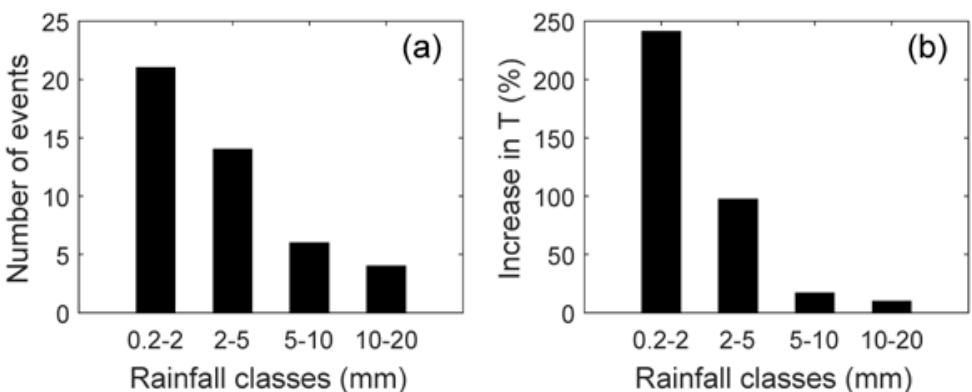

Figure 4 (a) Frequency of different rainfall amount classes; (b) Increase in transpiration (T) between the days before rain and the days after rain when $T$ peaked. There was only one day with $>20 \mathrm{~mm}$ rain and is not shown in the figure. Rain $\leq 0.2 \mathrm{~mm} / \mathrm{d}$ was considered as rain free.

\subsection{Responses of transpiration to environmental variables}

233 Relationships between $T$ and four environmental variables are shown in Figure 5. At the daily

234 scale, $R n$ and $V P D$ were, unsurprisingly, the two major factors influencing $T\left(R^{2}>0.50\right)$. Higher amount of $T$ corresponded to higher amount of $R n$ and VPD. In contrast, the effects of $T a$ and 
$236 \theta$ were not significant $\left(R^{2}=0.05\right)$ as there was barely a clear linear relationship between $T$ and 237 the two variables (bottom panels in Figure 5).
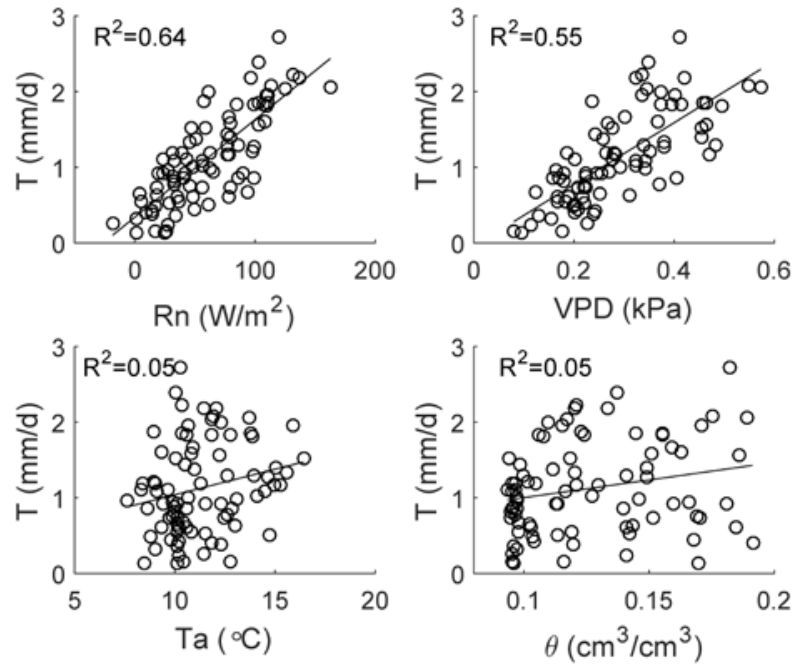

Figure 5 Relationships between transpiration $(T)$ and environmental variables: net radiation $(R n)$, vapor pressure deficit $(V P D)$, air temperature $(T a)$, and depth-average $(0-40 \mathrm{~cm})$ volumetric soil water content $(\theta)$. Solid lines are linear regressions between $T$ and the relevant variables.

243 When $T$, Ta and $\theta$ were analyzed according to different rainfall thresholds, the $R^{2}$ between $T$ and $T a$ were consistently low $(<0.10$, and mostly $p>0.05)$. However, relationships between $T$ and $\theta$ varied greatly with rainfall amounts (Figure 6). When rainfall was below $2.0 \mathrm{~mm}$ the soil water was important to maintain forest transpiration $\left(R^{2}>0.20, p<0.001\right)$. This effect decreased with increasing rainfall thresholds; when rainfall was between 2.0 and $4.0 \mathrm{~mm} / \mathrm{d}$ the effect was

248 still statistically significant $\left(R^{2}<0.10, p<0.05\right)$ but not as strong as below $2.0 \mathrm{~mm} / \mathrm{d}$. When rainfall was over $4.0 \mathrm{~mm} / \mathrm{d}$ there was no clear relationship between transpiration and soil water any more $\left(R^{2}<0.10, p>0.05\right)$. This indicates that the trees tend to deplete soil water storage

251 when there was little daily rainfall. 


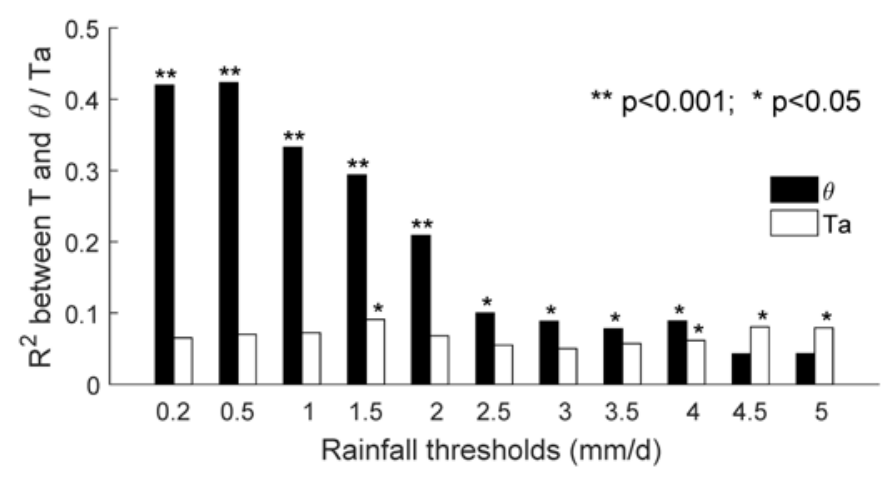

253

254

255

256

257

258

259

260

261

262

263

264

265

266

267

268

269
Figure 6 Coefficient of determination $\left(R^{2}\right)$ of linear regression between transpiration $(T)$ and soil water content $(\theta)$ and air temperature (Ta) below different rainfall thresholds. For example, the $R^{2}$ for rainfall threshold $1.5 \mathrm{~mm} / \mathrm{d}$ means $R^{2}$ between $T$ and $\theta / T a$ using data when rainfall is $\leq 1.5 \mathrm{~mm} / \mathrm{d}$.

Plant transpiration is regulated by stomata via stomatal conductance (and hence, canopy conductance). When transpiration was plotted against $T / V P D$, which serves as a proxy of canopy conductance (higher values correspond to higher $T$ rates), we observed a rapid increase of $T$ before $T / V P D \sim 4.0 \mathrm{~mm} / \mathrm{d} / \mathrm{kPa}$. Above this value, the increase was much less and plateaued. We therefore used this $T / V P D$ threshold $(4.0 \mathrm{~mm} / \mathrm{d} / \mathrm{kPa})$ to divide the data into two groups (below and above this threshold), and examined the environmental controls on transpiration again for these two data groups in Figure 7. The scatterplots show the different influences of atmospheric condition and soil water on transpiration with contrasting ranges of $T / V P D . R n$ and VPD were the two major influencing factors on transpiration on all occasions (Figure 7a, b). When $T / V P D$ was below $4.0 \mathrm{~mm} / \mathrm{d} / \mathrm{kPa}$, $T a$ showed weak influences on $T\left(R^{2}=0.27\right.$, $p<0.001)$, and $T$ was not related to $\theta\left(R^{2}=0.06, p=0.08\right)$. In contrast, when $T / V P D>4.0$ $\mathrm{mm} / \mathrm{d} / \mathrm{kPa}$, the relationship between $T$ and $\theta$ on was enhanced $\left(R^{2}=0.32, p<0.001\right)$ while $T a$ effect was minimal. 

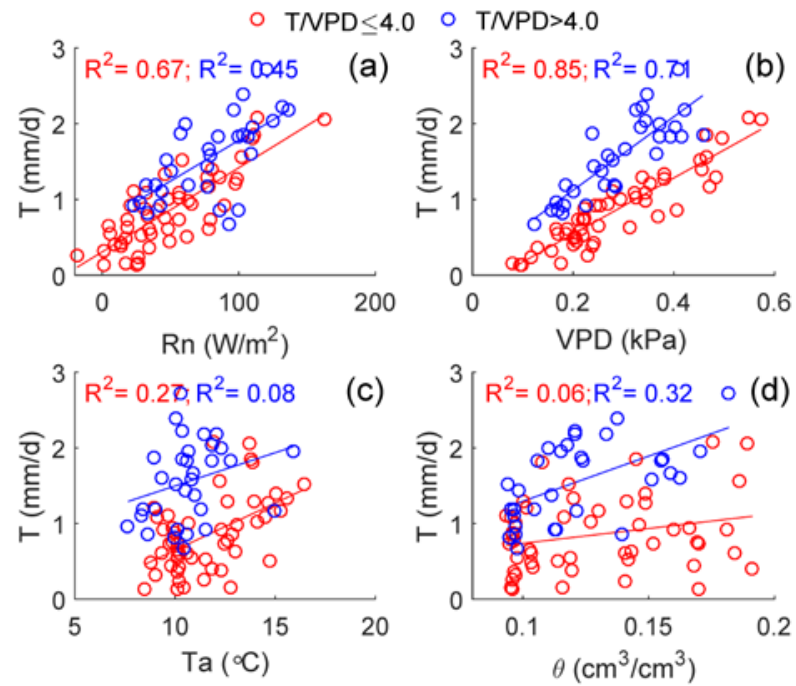

Figure 7 Relationships between transpiration $(T)$ and environmental variables with varying $T / V P D$ (unit: $\mathrm{mm} / \mathrm{d} / \mathrm{kPa}$ ). (a) $R n$-net radiation; (b) VPD-vapor pressure deficit; (c) Ta-air temperature; and (d) $\theta$-volumetric soil water content. Significance test $p$ values for $T$ and $T a$ relationship with $T / V P D>4.0$ and for $T$ and $\theta$ with $T / V P D \leq 4.0$ are 0.11 and 0.08 respectively, for others are $<0.001$.

\subsection{Partitioning of water supply to plant transpiration}

To understand the water sources for forest growth, we calculated the water balance between rainfall and transpiration on a weekly basis (Figure 8). Rainfall maintained the water stores in the forest and accounted for $98 \%$ of the variation in the $P$-T budget. In most of the 12 weeks, total rainfall exceeded the transpiration demand. Rainwater deficit $(P-T)$ existed only when weekly rainfall was below $\sim 8 \mathrm{~mm}$. It is noticeable that in the three weeks with rainfall deficit, transpiration did not decrease significantly but remained similar to previous weeks with more rainfall (Figure 8).It is also noteworthy that periods of deficits were limited, and the deficits were small. The regression between $P$ and $P$ - $T$ in Figure $8 \mathrm{~b}$ indicates that the forest used supplementary water supply from soil water storage when weekly rainfall was less than $\sim 8 \mathrm{~mm}$ on average. Rainfall here was the total gross rainfall, and although interception accounts for around $45 \%$ of summer precipitation (Braun, 2015), the effective rainfall should be sufficient to maintain transpiration in most weeks. 

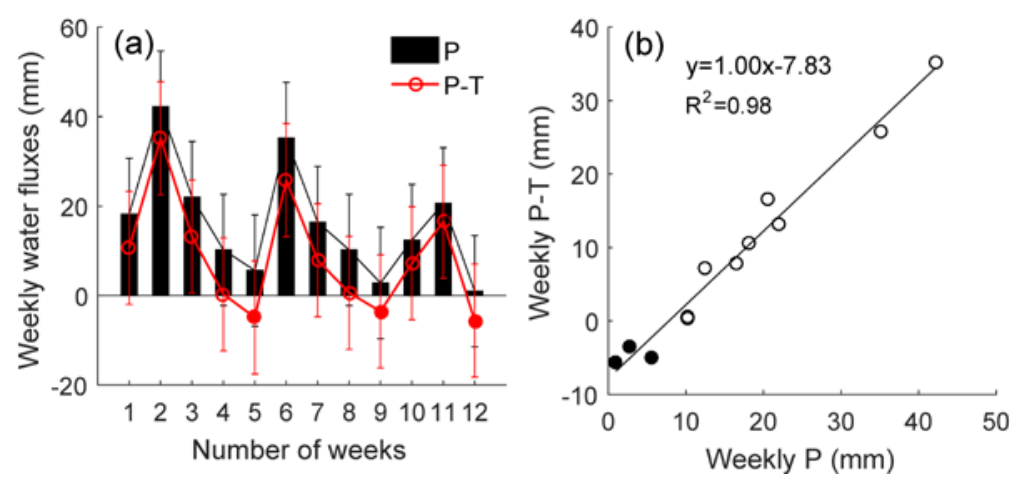

Figure 8 (a) Time series of weekly rainfall $(P)$ and water balance between rainfall and transpiration (T): $P-T$. (b) Regression between $P-T$ and $P$. Filled black circles correspond to the data points in (a). Error bars in (a) are one standard deviation of each data series: 12.4 $\mathrm{mm} /$ week for $P$ and $12.6 \mathrm{~mm} /$ week for $P-T$.

\section{Discussion}

\subsection{Transpiration in Scots pine forest and the environmental controls}

296

297

298

299

300

301

302

303

Average $T(1.1 \mathrm{~mm} / \mathrm{d})$ was low and coincident with low average atmospheric demand. $T$ values were at the low end of regional estimates across Europe $(1.2-1.8 \mathrm{~mm} / \mathrm{d}$ along a latitudinal range of $>20^{\circ} \mathrm{N}$ ), closest to the estimates at a Finnish site (Berninger, 1997; Meiresonne et al., 2003) and a Scottish site in the central Highlands (Haria and Price, 2000), and slightly lower than in a plot in central Scotland $(\sim 1.3 \mathrm{~mm} / \mathrm{d}$ from mid-May to end of August 1995 in Irvine et al., (1998)). The Scots pine water use in this study was generally within the range reported in studies conducted in wet temperate/boreal conifer forests (Unsworth et al., 2004; Barbour et al., 2005).

$R n$ and $V P D$ were the dominant variables restricting transpiration. The influence of $V P D$ on $T$ was similar to a temperate coniferous rainforest reported by Barbour et al. (2005) who showed a strong linear relationship between $T$ and $V P D$ when $V P D<0.6 \mathrm{kPa}$. This threshold of $V P D$ is lower than other reported values in a temperate hardwood forest and a boreal aspen forest (1.0 
kPa) by Bovard et al., (2005) and Hogg and Hurdle, (1997), respectively. Compared to Rn and $V P D$, the role of $T a$ in affecting $T$ is more ambiguous. $T a$ is often also regarded a major factor influencing forest water use (Jarvis, 1976; Zheng and Wang, 2015), but it is not always a

311 primary controlling factor (Lhomme et al., 1998; Wang et al., 2014). In fact, a number of

312 studies showed a more significant relationship between soil/leaf temperatures and transpiration

313 (Mellander et al., 2004; Pallas et al., 1967; Wieser et al., 2015). Results in this study also demonstrated no direct air temperature effect on transpiration.

315 The rapid increase in $T$ after rainfall probably cannot be simply attributed to rainfall 316 stimulation as reported for semi-arid areas (Zeppel et al., 2008; Huang and Zhang, 2016), where soil wetness clearly increased due to more rainfall and, in turn, increased $T$. Instead, compared to before-rain atmospheric condition, the exposure of canopy to increased solar radiation and reduced humidity was likely to be at least as important as the rainfall itself for an increased $T$. This is similar to Cory et al. (2013) where the increased biological activity indexed by $\mathrm{CO}_{2}$ release from soil carbon was due to intensified light exposure. This is also partly supported by the observations that $T$ increased more during smaller amount rainfall events (Figure 4) and that soil moisture dynamics (Figure 2c) were largely irresponsive to rainfall.

The influence of soil water on $T$ varied with rainfall amounts. $T$ was most clearly linked to soil water when rainfall was limited. This is consistent with Granier et al, (2007). The dependency declined as rainfall increased, and diminished when daily rain $>4 \mathrm{~mm} / \mathrm{d}$. This phenomenon could be the explained by the antecedent soil water storage built up in the rainy days (or months) that was depleted by trees later. Plants will adjust stomatal conductance in response to the changing atmospheric and soil water conditions (Buckley et al., 2003). The ratio T/VPD, a proxy of canopy conductance (Jarvis and McNaughton, 1986; Whitehead, 1998), helped to 
differentiate atmospheric and soil water controls on transpiration. In this study, soil water started to limit transpiration when $T / V P D>4 \mathrm{~mm} / \mathrm{d} / \mathrm{kPa}$, but otherwise not. This indicates that when trees transpired water at a higher rate, stomata regulation of $T$ in response to soil water limitation was triggered to prevent rapid water loss; while at the lower conductance rate, $T$ was more related to atmospheric conditions, near the potential rate, and stomatal regulation was barely involved (Tang et al., 2006; Tognetti et al., 2009). This phenomenon was also reported in Chen et al., (2014) with a different T/VPD threshold for a poplar plantation in Beijing, China.

\subsection{Implications for water partitioning}

Throughout the study period, $\sim 47 \%$ of rainfall returned to the atmosphere through transpiration in the plantation, $\sim 45 \%$ through canopy evaporation (Braun, 2015), and the rest to soil evaporation or deeper infiltration (Sprenger et al., 2017). Whilst the soil moisture sensors indicated little, if any, deeper recharge, their location under an area of denser canopy with likely high interception losses may have shown an extreme case and infiltration was likely higher where the canopy is less dense (Braun, 2015). With the projected future decrease in summer rain and increase in temperature in the area (Capell et al., 2013), the forest may contribute to more rainwater loss through transpiration and interception. Although increased rain intensity may reduce interception loss, with the context of decreased rain and increased transpiration, less groundwater recharge and runoff generation in summer can be expected (Sahin and Hall, 1996; Farley et al., 2005). Thus, the situation of relative summer "dry gets drier" (Feng and Zhang, 2015) could then be enhanced. There are proposals in the area to increase tree cover to maintain low temperatures in river channels for important species (Hrachowitz et al., 2010). Since the catchment is important to sustain local drinking water supplies and maintain important Atlantic salmon fisheries (Tetzlaff et al., 2008), assessing the effects of Scots pine trees on water partitioning and storage is important for water and land management. 
355

356

357

358

359

360

361

362

363

364

365

366

367

368

369

370

371

372

373

374

375

376

377

378

The $P$-T budgets indicate that for the study period, water re-cycling by the forest stand was rapid, with new inputs of rainfall quickly contributing to tree water uptake. This would be consistent with Scots pine having most of its roots in the upper $10 \mathrm{~cm}$ of the soil (Geris et al., 2015a) and would help explain why the soil moisture measurements at $10 \mathrm{~cm}$ showed no response to most rainfall events. However, in the driest weeks, antecedent deep soil water $(>0.4$ m) might help sustain transpiration (Schwinning et al., 2002; Chen et al., 2014). Moisture deficits in the deeper soil layers can only be relieved by large rain events because of high interception losses at the site (Braun, 2015) and root water uptake in the upper soil horizons limiting deeper percolation. Without enough replenishment from rainfall, the soil water (mainly stored from previous rainfall in the wet spring and early summer) continued to drop attributable mainly to transpiration and little to soil evaporation (Sprenger et al., 2017). There is no evidence showing the trees accessed groundwater in the dry summer (Geris et al., 2015a).

\section{Conclusions}

We analyzed Scots pine transpiration and its response to rainfall and four other environmental variables in a low-energy boreal Scottish forest. We investigated different rainfall effects on tree water use and the possible mechanism behind. Scots pine in this forest stand was characterized by rapid water recycling. The increase in transpiration was particularly large when daily rainfall was $<5 \mathrm{~mm}$, mainly ascribed to enhanced solar radiation on days after rain; while the increase was small to negligible when rainfall was over $5 \mathrm{~mm} / \mathrm{d}$ implying water stress was not marked. Daily variation of transpiration could be explained by radiation and atmospheric vapor pressure deficit. Air temperature was not a direct controlling factor in this environment. Soil water only became significant when rainfall was limited; and antecedent soil water from deep layers was depleted by the trees when there was a rainwater deficit. In total, the forest transpired $47 \%$ and intercepted $\sim 45 \%$ of rainfall in the study period, leaving $\sim 8 \%$ of 


\section{Acknowledgements}

383

384

385

386

We would like to thank The Leverhulme Trust (project PLATO, RPG-2014-016) and the European Research Council (ERC, project GA 335910 VeWa) for funding the projects in the catchment. We also want to thank two anonymous reviewers for providing valuable and constructive comments which substantially improved the paper.

\section{References}

Allen, R.G., Pereira, L.S., Raes, D., Smith, M., W, A.B., 1998. Crop evapotranspiration Guidelines for computing crop water requirements - FAO Irrigation and drainage paper 56. Irrig. Drain. 1-15. doi:10.1016/j.eja.2010.12.001

Arneth, a., Kelliher, F.M., Bauer, G., Hollinger, D.Y., Byers, J.N., Hunt, J.E., McSeveny, T.M., Ziegler, W., Vygodskaya, N.N., Milukova, I., Sogachov, A., Varlagin, A., Schulze, E.-D., 1996. Environmental regulation of xylem sap flow and total conductance of Larix gmelinii trees in eastern Siberia. Tree Physiol. 16, 247-255.

Asbjornsen, H., Tomer, M.D., Gomez-Cardenas, M., Brudvig, L.A., Greenan, C.M., Schilling, K., 2007. Tree and stand transpiration in a Midwestern bur oak savanna after elm encroachment and restoration thinning. For. Ecol. Manage. 247, 209-219. doi:10.1016/j.foreco.2007.04.043

Baltzer, J.L., Veness, T., Chasmer, L.E., Sniderhan, A.E., Quinton, W.L., 2014. Forests on thawing permafrost: Fragmentation, edge effects, and net forest loss. Glob. Chang. Biol. 20, 824-834. doi:10.1111/gcb.12349

Barbour, M.M., Hunt, J.E., Walcroft, A.S., Rogers, G.N.D., McSeveny, T.M., Whitehead, D., 2005. Components of ecosystem evaporation in a temperate coniferous rainforest, with canopy transpiration scaled using sapwood density. New Phytol. 165, 549-558. doi:10.1111/j.1469-8137.2004.01257.x

Barichivich, J., Briffa, K.R., Myneni, R., van der Schrier, G., Dorigo, W., Tucker, C.J., Osborn, T.J., Melvin, T.M., 2014. Temperature and snow-mediated moisture controls of summer photosynthetic activity in northern terrestrial ecosystems between 1982 and 2011. Remote Sens. 6, 1390-1431. doi:10.3390/rs6021390

Beringer, J., Chapin, F.S., Thompson, C.C., McGuire, A.D., 2005. Surface energy exchanges along a tundra-forest transition and feedbacks to climate. Agric. For. Meteorol. 131, 143161. doi:10.1016/j.agrformet.2005.05.006

Berninger, F., 1997. Effects of drought and phenology on GPP in Pinus sylvestris: A simulation 
study along a geographical gradient. Funct. Ecol. 11, 33-42. doi:10.1046/j.13652435.1997.00051.x

Birkel, C., Tetzlaff, D., Dunn, S.M., Soulsby, C., 2011. Using time domain and geographic source tracers to conceptualize streamflow generation processes in lumped rainfall-runoff models. Water Resour. Res. 47. doi:10.1029/2010WR009547

Blumstock, M., Tetzlaff, D., Dick, J.J., Nuetzmann, G., Soulsby, C., 2016. Spatial organization of groundwater dynamics and streamflow response from different hydropedological units in a montane catchment. Hydrol. Process. 30, 3735-3753. doi:10.1002/hyp.10848

Bovard, B.D., Curtis, P.S., Vogel, C.S., Su, H.-B., Schmid, H.P., 2005. Environmental controls on sap flow in a northern hardwood forest. Tree Physiol. 25, 31-38. doi:10.1093/treephys/25.1.31

Braun, H., 2015. Influence of vegetation on precipitation partitioning and isotopic composition in northern upland catchments. University of Freiburg; University of Aberdeen.

Brooks, J.R., 2015. Water, bound and mobile. Science (80-. ). 349, 138-139. doi:10.1126/science.aac4742

Buckley, T.N., Mott, K.A., Farquhar, G.D., 2003. A hydromechanical and biochemical model of stomatal conductance. Plant, Cell Environ. 26, 1767-1785. doi:10.1046/j.13653040.2003.01094.x

Buitenwerf, R., Rose, L., Higgins, S.I., 2015. Three decades of multi-dimensional change in global leaf phenology. Nat. Clim. Chang. 5, 364-368. doi:10.1038/nclimate2533

Callaghan, T. V, Jonasson, C., Thierfelder, T., Yang, Z., Hedenås, H., Johansson, M., Molau, U., Van Bogaert, R., Michelsen, A., Olofsson, J., Gwynn-Jones, D., Bokhorst, S., Phoenix, G., Bjerke, J.W., Tømmervik, H., Christensen, T.R., Hanna, E., Koller, E.K., Sloan, V.L., 2013. Ecosystem change and stability over multiple decades in the Swedish subarctic: complex processes and multiple drivers. Philos. Trans. R. Soc. Lond. B. Biol. Sci. 368, 20120488. doi:10.1098/rstb.2012.0488

Capell, R., Tetzlaff, D., Soulsby, C., 2013. Will catchment characteristics moderate the projected effects of climate change on flow regimes in the Scottish Highlands? Hydrol. Process. 27, 687-699. doi:10.1002/hyp.9626

Cavanaugh, M.L., Kurc, S.A., Scott, R.L., 2011. Evapotranspiration partitioning in semiarid shrubland ecosystems: A two-site evaluation of soil moisture control on transpiration. Ecohydrology 4, 671-681. doi:10.1002/eco.157

Chen, L., Zhang, Z., Zha, T., Mo, K., Zhang, Y., Fang, X., 2014. Soil water affects transpiration response to rainfall and vapor pressure deficit in poplar plantation. New For. 45, 235-250. doi:10.1007/s11056-014-9405-0

Chertov, O., Bhatti, J.S., Komarov, A., 2010. Impact of temperature increase and precipitation alteration at climate change on forest productivity and soil carbon in boreal forest ecosystems in Canada and Russia: simulation approach with the EFIMOD model. Clim. Chang. Var. 303-326. doi:10.5772/9814

Cory, R.M., Crump, B.C., Dobkowski, J.A., Kling, G.W., 2013. Surface exposure to sunlight stimulates $\mathrm{CO} 2$ release from permafrost soil carbon in the Arctic. Proc. Natl. Acad. Sci. U. S. A. 110, 3429-34. doi:10.1073/pnas.1214104110

Deutscher, J., Kupec, P., Dundek, P., Holík, L., Machala, M., Urban, J., 2016. Diurnal dynamics of streamflow in an upland forested micro-watershed during short precipitationfree periods is altered by tree sap flow. Hydrol. Process. 30, 2042-2049. doi:10.1002/hyp.10771

Dick, J.J., Tetzlaff, D., Soulsby, C., 2015. Landscape influence on small-scale water temperature variations in a moorland catchment. Hydrol. Process. 29, 3098-3111. doi:10.1002/hyp.10423

Doody, T.M., Holland, K.L., Benyon, R.G., Jolly, I.D., 2009. Effect of groundwater freshening 
on riparian vegetation water balance. Hydrol. Process. 23, 3485-3499. doi:10.1002/hyp.7460

Dore, M.H.I., 2005. Climate change and changes in global precipitation patterns: What do we know? Environ. Int. doi:10.1016/j.envint.2005.03.004

Easterling, D.R., Evans, J.L., Groisman, P.Y., Karl, T.R., Kunkel, K.E., Ambenje, P., 2000. Observed variability and trends in extreme climate events: A brief review. Bull. Am. Meteorol. Soc. doi:10.1175/1520-0477(2000)081<0417:OVATIE >2.3.CO;2

Farley, K.A., Jobbágy, E.G., Jackson, R.B., 2005. Effects of afforestation on water yield: A global synthesis with implications for policy. Glob. Chang. Biol. 11, 1565-1576. doi:10.1111/j.1365-2486.2005.01011.x

Feng, H., Zhang, M., 2015. Global land moisture trends: drier in dry and wetter in wet over land. Sci. Rep. 5, 18018. doi:10.1038/srep18018

Findell, K.L., Eltahir, E.A.B., 1997. An analysis of the soil moisture-rainfall feedback, based on direct observations from Illinois. Water Resour. Res. 33, 725. doi:10.1029/96WR03756

Gao, Y., Markkanen, T., Aurela, M., Mammarella, I., Thum, T., Tsuruta, A., Yang, H., Aalto, T., 2016. Response of water use efficiency to summer drought in boreal Scots pine forests in Finland. Biogeosciences Discuss. 5194, 1-18. doi:10.5194/bg-2016-198

Garonna, I., de Jong, R., Schaepman, M.E., 2016. Variability and evolution of global land surface phenology over the past three decades (1982-2012). Glob. Chang. Biol. 22, 14561468. doi:10.1111/gcb.13168

Gazal, R.M., Scott, R.L., Goodrich, D.C., Williams, D.G., 2006. Controls on transpiration in a semiarid riparian cottonwood forest. Agric. For. Meteorol. 137, 56-67. doi:10.1016/j.agrformet.2006.03.002

Geris, J., Tetzlaff, D., Mcdonnell, J., Anderson, J., Paton, G., Soulsby, C., 2015a. Ecohydrological separation in wet, low energy northern environments? A preliminary assessment using different soil water extraction techniques. Hydrol. Process. 29, 51395152. doi:10.1002/hyp.10603

Geris, J., Tetzlaff, D., Soulsby, C., 2015b. Resistance and resilience to droughts: Hydropedological controls on catchment storage and run-off response. Hydrol. Process. 29, 4579-4593. doi:10.1002/hyp.10480

Gosling, R., 2012. Assessing the impact of projected climate change on drought vulnerability in Scotland Scotland. Hydrol. Res. 45, 806-817. doi:10.2166/nh.2014.148

Granier, A., 1987. Evaluation of transpiration in a Douglas-fir stand by means of sap flow measurements. Tree Physiol. 3, 309-320.

Granier, A., Huc, R., Barigah, S.T., 1996. Transpiration of natural rain forest and its dependence on climatic factors. Agric. For. Meteorol. 78, 19-29. doi:10.1016/01681923(95)02252-X

Granier, A., Reichstein, M., Bréda, N., Janssens, I.A., Falge, E., Ciais, P., Grünwald, T., Aubinet, M., Berbigier, P., Bernhofer, C., Buchmann, N., Facini, O., Grassi, G., Heinesch, B., Ilvesniemi, H., Keronen, P., Knohl, A., Köstner, B., Lagergren, F., Lindroth, A., Longdoz, B., Loustau, D., Mateus, J., Montagnani, L., Nys, C., Moors, E., Papale, D., Peiffer, M., Pilegaard, K., Pita, G., Pumpanen, J., Rambal, S., Rebmann, C., Rodrigues, A., Seufert, G., Tenhunen, J., Vesala, T., Wang, Q., 2007. Evidence for soil water control on carbon and water dynamics in European forests during the extremely dry year: 2003. Agric. For. Meteorol. 143, 123-145. doi:10.1016/j.agrformet.2006.12.004

Guo, W., Li, B., Zhang, X., Wang, R., 2010. Effects of water stress on water use efficiency and water balance components of Hippophae rhamnoides and Caragana intermedia in the soilplant-atmosphere continuum. Agrofor. Syst. 80, 423-435. doi:10.1007/s10457-010-93374 
Haria, A.H., Price, D.J., 2000. Evaporation from Scots pine (Pinus sylvestris) following natural re-colonisation of the Cairngorm mountains, Scotland. Hydrol. Earth Syst. Sci. 4, 451461. doi:10.5194/hess-4-451-2000

Hogg, E.H., Hurdle, P. a., 1997. Sap flow in trembling aspen: implications for stomatal responses to vapor pressure deficit. Tree Physiol. 17, 501-509. doi:10.1093/treephys/17.8-9.501

Hrachowitz, M., Soulsby, C., Imholt, C., Malcolm, I.A., Tetzlaff, D., 2010. Thermal regimes in a large upland salmon river: a simple model to identify the influence of landscape controls and climate change on maximum temperatures. Hydrol. Process. 24, 3374-3391. doi:10.1002/hyp.7756

Huang, L., Zhang, Z., 2016. Effect of rainfall pulses on plant growth and transpiration of two xerophytic shrubs in a revegetated desert area: Tengger Desert, China. CATENA 137, 269-276. doi:10.1016/j.catena.2015.09.020

IPCC, 2013. Climate Change 2013: The Physical Science Basis. Contribution of Working Group I to the Fifth Assessment Report of the Intergovernmental Panel on Climate Change. Cambridge, United Kingdom and New York, NY, USA. doi:10.1017/CBO9781107415324

Irvine, J., Perks, M.P., Magnani, F., Grace, J., 1998. The response of Pinus sylvestris to drought: stomatal control of transpiration and hydraulic conductance. Tree Physiol. 18, 393-402. doi:10.1093/treephys/18.6.393

Jarvis, P.G., 1976. The Interpretation of the Variations in Leaf Water Potential and Stomatal Conductance Found in Canopies in the Field. Philos. Trans. R. Soc. London B Biol. Sci. 273.

Jarvis, P.G., McNaughton, K.G., 1986. Stomatal Control of Transpiration: Scaling Up from Leaf to Region. Adv. Ecol. Res. 15, 1-49. doi:10.1016/S0065-2504(08)60119-1

Jorgenson, M.T., Shur, Y.L., Pullman, E.R., 2006. Abrupt increase in permafrost degradation in Arctic Alaska. Geophys. Res. Lett. 33. doi:10.1029/2005GL024960

Krasting, J.P., Broccoli, A.J., Dixon, K.W., Lanzante, J.R., 2013. Future changes in northern hemisphere snowfall. J. Clim. 26, 7813-7828. doi:10.1175/JCLI-D-12-00832.1

Kropp, H., Loranty, M., Alexander, H.D., Berner, L.T., Natali, S.M., Spawn, S.A., 2017. Environmental constraints on transpiration and stomatal conductance in a Siberian Arctic boreal forest. J. Geophys. Res. Biogeosciences. doi:10.1002/2016JG003709

Le Maitre, D.C., Scott, D.F., Colvin, C., 1999. A review of information on interactions between vegetation and groundwater. Water SA 25, 137-152.

Lhomme, J.P., Elguero, E., Chehbouni, A., Boulet, G., 1998. Stomatal control of transpiration: Examination of Monteith's formulation of canopy resistance. Water Resour. Res. 34, 2301-2308. doi:10.1029/98WR01339

Lindner, M., Garcia-Gonzalo, J., Kolström, M., Green, T., Reguera, R., Maroschek, M., Seidl, R., Lexer, M.J., Netherer, S., Schopf, A., Kremer, A., Delzon, S., Barbati, A., Marchetti, M., Corona, P., 2008. Impacts of Climate Change on European Forests and Options for Adaptation.

Lisar, S.Y.S., Motafakkerazad, R., Hossain, M.M., Rahman, I.M.M., 2012. Water Stress in Plants : Causes , Effects and Responses. Water Stress 1-14. doi:10.5772/39363

Luus, K.A., Gel, Y., Lin, J.C., Kelly, R.E.J., Duguay, C.R., 2013. Pan-Arctic linkages between snow accumulation and growing-season air temperature, soil moisture and vegetation. Biogeosciences 10, 7575-7597. doi:10.5194/bg-10-7575-2013

McLaren, J.D., Arain, M.A., Khomik, M., Peichl, M., Brodeur, J., 2008. Water flux components and soil water-atmospheric controls in a temperate pine forest growing in a well-drained sandy soil. J. Geophys. Res. Biogeosciences 113. doi:10.1029/2007JG000653 
Meiresonne, L., Sampson, D.A., Kowalski, A.S., Janssens, I.A., Nadezhdina, N., Cermák, J., Van Slycken, J., Ceulemans, R., 2003. Water flux estimates from a Belgian Scots pine stand: A comparison of different approaches. J. Hydrol. 270, 230-252. doi:10.1016/S0022-1694(02)00284-6

Mellander, P.E., Bishop, K., Lundmark, T., 2004. The influence of soil temperature on transpiration: A plot scale manipulation in a young Scots pine stand. For. Ecol. Manage. 195, 15-28. doi:10.1016/j.foreco.2004.02.051

Natali, S.M., Schuur, E.A.G., Mauritz, M., Schade, J.D., Celis, G., Crummer, K.G., Johnston, C., Krapek, J., Pegoraro, E., Salmon, V.G., Webb, E.E., 2015. Permafrost thaw and soil moisture driving $\mathrm{CO} 2$ and $\mathrm{CH} 4$ release from upland tundra. J. Geophys. Res. Biogeosciences 120, 525-537. doi:10.1002/2014JG002872

Ogle, K., Reynolds, J.F., 2004. Plant responses to precipitation in desert ecosystems: Integrating functional types, pulses, thresholds, and delays. Oecologia 141, 282-294. doi:10.1007/s00442-004-1507-5

Pallas, J.E., Michel, B.E., Harris, D.G., 1967. Photosynthesis, Transpiration, Leaf Temperature, and Stomatal Activity of Cotton Plants under Varying Water Potentials. Plant Physiol. 42, 76-88. doi:10.1104/pp.42.1.76

Pearson, R.G., Phillips, S.J., Loranty, M.M., Beck, P.S.A., Damoulas, T., Knight, S.J., Goetz, S.J., 2013. Shifts in Arctic vegetation and associated feedbacks under climate change. Nat. Clim. Chang. 3, 673-677. doi:10.1038/nclimate1858

Porporato, A., Laio, F., Ridolfi, L., Rodriguez-Iturbe, I., 2001. Plants in water-controlled ecosystems: active role in hydrologic processes and response to water stress: III. Vegetation water stress. Adv. Water Resour. 24, 725-744. doi:10.1016/S03091708(01)00006-9

Potts, D.L., Huxman, T.E., Cable, J.M., English, N.B., Ignace, D.D., Eilts, J.A., Mason, M.J., Weltzin, J.F., Williams, D.G., 2006. Antecedent moisture and seasonal precipitation influence the response of canopy-scale carbon and water exchange to rainfall pulses in a semi-arid grassland. New Phytol. 170, 849-860. doi:10.1111/j.1469-8137.2006.01732.x

Raz-Yaseef, N., Yakir, D., Schiller, G., Cohen, S., 2012. Dynamics of evapotranspiration partitioning in a semi-arid forest as affected by temporal rainfall patterns. Agric. For. Meteorol. 157, 77-85. doi:10.1016/j.agrformet.2012.01.015

Ruckstuhl, K.E., Johnson, E.A., Miyanishi, K., 2008. Introduction. The boreal forest and global change. Philos. Trans. R. Soc. Lond. B. Biol. Sci. 363, 2245-2249. doi:10.1098/rstb.2007.2196

Sahin, V., Hall, M.J., 1996. The effects of afforestation and deforestation on water yields. J. Hydrol. 178, 293-309. doi:10.1016/0022-1694(95)02825-0

Schulze, E.-D., Kelliher, F.M., Korner, C., Lloyd, J., Leuning, R., 1994. Relationships among maximum stomatal conductance, ecosystem surface conductance, carbon assimilation rate, and plant nitrogen nutrition: a global ecology scaling exercise, Annual Review of Ecology and Systematics. doi:10.1146/annurev.es.25.110194.003213

Schwinning, S., Davis, K., Richardson, L., Ehleringer, J.R., 2002. Deuterium enriched irrigation indicates different forms of rain use in shrub/grass species of the Colorado Plateau. Oecologia 130, 345-355. doi:10.1007/s00442-001-0817-0

Soulsby, C., Birkel, C., Geris, J., Dick, J., Tunaley, C., Tetzlaff, D., 2015. Stream water age distributions controlled by storage dynamics and nonlinear hydrologic connectivity: Modeling with high-resolution isotope data. Water Resour. Res. 51, 7759-7776. doi:10.1002/2015WR017888

Sprenger, M., Tetzlaff, D., Tunaley, C., Dick, J., Soulsby, C., 2017. Evaporation fractionation in a peatland drainage network affects stream water isotope composition. Water Resour. Res. 53, 851-866. 
Tang, J., Bolstad, P. V., Ewers, B.E., Desai, A.R., Davis, K.J., Carey, E. V., 2006. Sap fluxupscaled canopy transpiration, stomatal conductance, and water use efficiency in an old growth forest in the Great Lakes region of the United States. J. Geophys. Res. Biogeosciences 111, n/a-n/a. doi:10.1029/2005JG000083

Tetzlaff, D., Birkel, C., Dick, J., Geris, J., Soulsby, C., 2014. Storage dynamics in hydropedological units control hillslope connectivity, runoff generation, and the evolution of catchment transit time distributions. Water Resour. Res. 50, 969-985. doi:10.1002/2013WR014147

Tetzlaff, D., Gibbins, C., Bacon, P.J., Youngson, A.F., Soulsby, C., 2008. Influence of hydrological regimes on the pre-spawning entry of Atlantic Salmon (Salmo Salar L.) into an upland river, in: River Research and Applications. John Wiley \& Sons, Ltd., pp. 528542. doi:10.1002/rra.1144

Tognetti, R., Giovannelli, A., Lavini, A., Morelli, G., Fragnito, F., D’Andria, R., 2009. Assessing environmental controls over conductances through the soil-plant-atmosphere continuum in an experimental olive tree plantation of southern Italy. Agric. For. Meteorol. 149, 1229-1243. doi:10.1016/j.agrformet.2009.02.008

Trahan, M.W., Schubert, B.A., 2016. Temperature-induced water stress in high-latitude forests in response to natural and anthropogenic warming. Glob. Chang. Biol. 22, 782-791. doi:10.1111/gcb.13121

Unsworth, M., Phillips, N., Link, T., Bond, B., Falk, M., Harmon, M., Hinckley, T., Marks, D., Paw U, K., 2004. Components and Controls of Water Flux in an Old-growth Douglasfir?Western Hemlock Ecosystem. Ecosystems 7, 468-481. doi:10.1007/s10021-0040138-3

Vivoni, E.R., Rinehart, A.J., Méndez-Barroso, L.A., Aragón, C.A., Bisht, G., Cardenas, M.B., Engle, E., Forman, B.A., Frisbee, M.D., Gutiérrez-Jurado, H.A., Hong, S., Mahmood, T.H., Tai, K., Wyckoff, R.L., 2008. Vegetation controls on soil moisture distribution in the Valles Caldera, New Mexico, during the North American monsoon. Ecohydrology 1, 225-238. doi:10.1002/eco.11

Wang, H., Guan, H., Deng, Z., Simmons, C.T., 2014. Optimization of canopy conductance models from concurrent measurements of sap flow and stem water potential on Drooping Sheoak in South Australia. Water Resour. Res. 50, 6154-6167. doi:10.1002/2013WR014818

Wang, H., Guan, H., Simmons, C.T., 2016. Modeling the environmental controls on tree water use at different temporal scales. Agric. For. Meteorol. 225, 24-35. doi:10.1016/j.agrformet.2016.04.016

Whitehead, D., 1998. Regulation of stomatal conductance and transpiration in forest canopies. Tree Physiol. 18, 633-644. doi:10.1093/treephys/18.8-9.633

Whitley, R., Taylor, D., Macinnis-Ng, C., Zeppel, M., Yunusa, I., O’Grady, A., Froend, R., Medlyn, B., Eamus, D., 2013. Developing an empirical model of canopy water flux describing the common response of transpiration to solar radiation and VPD across five contrasting woodlands and forests. Hydrol. Process. 27, 1133-1146. doi:10.1002/hyp.9280

Wieser, G., Grams, T.E.E., Matyssek, R., Oberhuber, W., Gruber, A., 2015. Soil warming increased whole-tree water use of Pinus cembra at the treeline in the Central Tyrolean Alps. Tree Physiol. 35, 279-288. doi:10.1093/treephys/tpv009

Zeppel, M., Macinnis-Ng, C.M.O., Ford, C.R., Eamus, D., 2008. The response of sap flow to pulses of rain in a temperate Australian woodland. Plant Soil 305, 121-130. doi:10.1007/s11104-007-9349-7

Zha, T., Li, C., Kellomäki, S., Peltola, H., Wang, K.Y., Zhang, Y., 2013. Controls of Evapotranspiration and CO2 Fluxes from Scots Pine by Surface Conductance and Abiotic 
Factors. PLoS One 8. doi:10.1371/journal.pone.0069027

665

Zhang, K., Kimball, J.S., Hogg, E.H., Zhao, M., Oechel, W.C., Cassano, J.J., Running, S.W., 2008. Satellite-based model detection of recent climate-driven changes in northern high-

668 latitude vegetation productivity. J. Geophys. Res. Biogeosciences 113, G03033.

669 doi:10.1029/2007JG000621

670

671

672

673

674

675

Zhao, W., Liu, B., 2010. The response of sap flow in shrubs to rainfall pulses in the desert region of China. Agric. doi:10.1016/j.agrformet.2010.05.012

Zheng, C., Wang, Q., 2015. Seasonal and annual variation in transpiration of a dominant desert species, Haloxylon ammodendron , in Central Asia up-scaled from sap flow measurement. Ecohydrology 8, 948-960. doi:10.1002/eco.1547 